THEMATIC SPACE: SOCIAL PROTECTION IN CONTEMPORARY CAPITALISM:

COUNTER-REFORMS AND REGRESSION OF SOCIAL RIGHTS

\title{
Analysis of labor policies in Brazil: How can Marx contribute?
}

\author{
Alexandre Aranha Arbia ${ }^{1}$ \\ https://orcid.org/0000-0002-3474-9170 \\ ${ }^{1}$ Universidade Federal de Ouro Preto, Departamento de Serviço Social, Mariana, MG, Brazil
}

\section{Analysis of labor policies in Brazil: How can Marx contribute?}

Abstract: This article uses the Marxian analysis of the nineteenth century English factory legislation, to demonstrate how a concrete approach to labor policy in Brazil can be inspired by the guidelines included in the Volume I of Das Kapital. The article covers the period from the regulation established by President Vargas, to the wild deregulation proposed by President Temer, exposing the links between capital accumulation and the Brazilian labor policies.

Keywords: Das Kapital. Capital accumulation in Brazil. Political-legal labor regulation in Brazil. Marx.

Submitted on June 2, 2018. Approved on September 18, 2018. Reviewed on December 4, 2019.

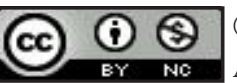

(C) The Author(s). 2019 Open Access This article is distributed under the terms of the Creative Commons Attribution-NonCommercial 4.0 International License (http://creativecommons.org/licenses/by-nc/4.0/), which permits use, distribution, and reproduction in any medium, since it's for non-commercial purposes, and provided you give appropriate credit to the original author(s) and the source, provide a link to the Creative Commons license, and indicate if changes were made. 


\section{Introduction}

Lasciate ogne speranza, voi ch'intrate. (Alighieri, 1933, p. 12)

A question that is continuously found in the background of the debate on policies related to the laborpower in Brazil throughout modern history is: what state do we want? For some, it is possible to reach the levels of accumulation observed in societies working in the classical way (Chasin, 2000, p. 38), based on their full institutionality. The advocates of this idea fail to realize the particular constitution of our capital, of the colonial way (Chasin, 2000, p. 54) - we struggle to follow through, at the core of our capitalist constitution, and fail to realize the costs related to this context.

This article is based on a resumption of the Marxian analyzes of the labor-power as a commodity and the nineteenth century English Factory Acts, present in Volume I of Das Kapital. It aims to contribute so that we do not lose sight of the statement of the Florentine poet: "Abandon hope all ye who enter here," when dealing with capital, and in particular when we look at the process related to the Brazilian state and capital accumulation in the country. The intention is to show that, considering the national particularities in expressing the general tendency of the way capital takes over the labor-power, it is not possible to expect anything from the Brazilian state (taken as a manifestation of the modern state ${ }^{1}$ ) and from the national bourgeoisie, other than the absolute predation of labor-power. The explicit expression of this understanding is the recent dismantling of labor legislation, resumed in $2015^{2}$ and consolidated in 2017 (Lei No. 13.467).

We will discuss from the Marxian analysis to the real determinants of Brazilian society, arguing that, regarding the national capital and the state, history only surprises those who do not understand history ${ }^{3}$ (Chasin, 2000, p. 79).

\section{Entrance to Dis: The labor-power as a mere commodity}

No reading of Volume I of Das Kapital can fail to note the extreme objectivity of Marx when exposing how the capital works. In a characteristic style and without ever acceding to the subjectivism, Marx always explains the object as it is; never as he would like it to be.

When closely following Marx's exposition of the English labor legislation (and its consequences) in the nineteenth century, it is clear that the discussion occurs in a context of extremely unhealthy and inhumane working conditions in the various branches of industrial production. Some of the elements well described in Marx works are the brutal infant mortality rates (Marx, 2006a), the increase in cases of alcoholism and the lack of protection of children and adolescents, the dramatic living conditions of workers in a period where forms of manufacturing and the possibility of working from home were overcome by machines (Marx, 2006a). These elements put us before horrors worthy of a Dantesque scene.

The cases are approached with a rich document source, and show a phenomenon that is not well remembered, despite its obviousness: the tendency to physically destroy the labor-power, promoted by the free ascendancy of the competitive capital. This capital is kept in misgovernment, and would end up jeopardizing, in the medium term, the process of accumulation at the systemic level. According to Marx's (2006a) perspective:

If the Règlement organique of the Danubian provinces was a positive expression of the greed for surplus labor which every paragraph legalized, the English Factory Acts are the negative expression of the same greed [emphasis added]. These acts curb the passion of capital for a limitless draining of laborpower, by forcibly limiting the working day by state regulations, made by a state that is ruled by capitalist and landlord [emphasis added]. Apart from the working-class movement that daily grew more threatening, the limiting of factory labor was dictated by the same necessity which spread guano over the English fields. The same blind eagerness for plunder that in the one case exhausted the soil had, in the other, torn up by the roots the living force of the nation [emphasis added]. Periodical epidemics speak on this point as clearly as the diminishing military standard in Germany and France. (pp. 277-278)

It is clear both the need to restrain the capital avidity that tends to physically annihilate the labor-power; and the need to restrain the working class movement that daily grew more threatening (Marx, 2006a, p. 277). Therefore, in the event of an uprising, at best, it may call into question the continuity of the valorization process or ultimately implode the bourgeois society. It should be noted that in both cases we are faced with a need for social capital to correct structuring contradictions generated by this cannibalistic movement and its constitutive 
units. In the first case, the reduction of the labor-power - due to: a) the worsening of the workers' conditions of physiological reproduction (maintaining unhealthy conditions and mortality); and b) the supply of (abstract) average work tends to be established in gradually lower social levels - compromises the ascendancy of the accumulation (disregarding, in a first moment, the elevation of the organic composition in a scenario based on the intensive use of labor-power). In the second, it is a matter of guaranteeing the current social order, put at risk by the possibility of an action, ultimately meta-political (a social revolution), of the proletariat. The Factory Acts are the legal-political solution to contain both cases.

In the pages that follow, Marx (2006a) reproduces the Report of the Committee on the Baking Trade in Ireland for 1861. The report, after the uprising of bakery workers against night work and working on Sundays in 1858 and 1860, evaluates working conditions in bakeries of Ireland:

The Committee believe that the hours of labor are limited by natural laws, which cannot be violated with impunity. That for master bakers to induce their workmen, by the fear of losing employment, to violate their religious convictions and their better feelings, to disobey the laws of the land, and to disregard public opinion [emphasis added] (this all refers to Sunday labor ${ }^{4}$ ), is calculated to provoke ill-feeling between workmen and masters, ... and affords an example dangerous [emphasis added] to religion, morality, and social order... The Committee believe that any constant work beyond 12 hours a-day [emphasis added] encroaches on the domestic and private life of the working-man, and so leads to disastrous moral results, interfering with each man's home, and the discharge of his family duties [emphasis added] as a son, a brother, a husband, a father. That work beyond 12 hours has a tendency to undermine the health of the workingman, and so leads to premature old age and death [emphasis added], to the great injury of families of working-men, thus deprived of the care and support of the head of the family when most required. (as cited in Marx, 2006a, pp. 292-293)

Apart from the fact that the work "beyond 12 hours-a-day" (as cited in Marx, 2006a, p. 293) jeopardizes the vigor and reproduction of the labor-power, disobedience to the law and the disrespect of business owners for public opinion catches the attention of the members of the governmental committee. It is important to observe how, from the point of view of the members of the committee, the process that goes from the exaggerated demands of work to the noncompliance with law and order is a process that leads to the denial of legal solution and, thus, to barbarism, as expressed in the report "an example dangerous to religion, morality, and social order" (as cited in Marx, 2006a, p. 292). The fear is that an uprising of workers inspired by the dangerous example, can escape the ideological solution of law and order and seek a solution by their means, challenging the regular operation of capital on a social scale (operation which, from the point of view of the commission, represents the civilized order).

Following Marx's trend of thought, after a dramatic demonstration of data ${ }^{5}$ on infant mortality in English districts - with rates reaching, in 1864, approximately $27 \%$ (Marx, 2006a) -, a fundamental consideration is the "leveling" nature of capital. This nature allows to understand both the process of generalization of the Factory Acts for all sectors of industrial production and the efforts of individual capital to circumvent the law. Marx (2006a) exposes this tendency of capital:

But since capital is by nature a leveler, since it exacts in every sphere of production equality in the conditions of the exploitation of labor, the limitation by law of children's labor, in one branch of industry, becomes the cause of its limitation in others. (p. 454)

First, when a level of exploitation adequate to the needs of the global capital of social preservation of the commodity labor-power is established, breaking the law becomes extremely advantageous for individual capitals: not only can they rely individually on a labor-power socially given in better physical conditions, but can also increase their rate of surplus-value at the system's expense ${ }^{6}$. This context clarifies the inherent tension between legal constraints, imposed as a way of preserving capital on a systemic scale (which takes the form, by law, of an advance by the State against capital in general, reinforcing its "public" nature), and the units of capital. All these limitations in form of legal impositions, concern rather the capital structural needs to contain its centrifugal forces (physical annihilation of the commodity labor-power' and uprisings that may implode the systemic functioning of value), than the achievements, even if motivated by the opposing movement of workers, whose uprising has often led historically to violent actions (explicit denials of law and politics).

After the enactment of the 1850 legislation ${ }^{7}$, a wide tension was established between the industries subject to the Factory Acts and the others left without regulation. In the case of the former, the limitation of the 10-hour workday, combined with the intensive use of machines, increased the pace of work, concentrated on 
the same worker functions previously performed by two or three employees. Productivity increased and, consequently, there was an expansion in exploitation and exhaustion, as well as the new conditions leading to lowering of wages by the increase of relative surplus population, as a result of the massive replacement of living for dead labor. The unregulated industries saw all kinds of exploitation and destruction of the labor-power, until finally the extension of the Factory Acts to home workers, in 1864, led to the collapse of the archaic forms of labor exploitation. This tension, established before the generalization of the Factory Acts, brought about a certain cynical outcry by certain sectors of the bourgeoisie for the extension of legal regulation in the name of civility and public order, as can be seen in the words of J. Simpson (entrepreneur producing paper-bag and cardboard boxes), which apparently (at least as is commonly understood) subverts the very logic of capital's operation. Marx reproduces parts of the Children's Employment Commission reports. The entrepreneur J. Simpson declares to the commission that he:

"would sign any petition for it" (legislative interference ${ }^{8}$ ) ... "As it was, he always felt restless at night, when he had closed his place, lest others should be working later than him and getting away his orders." Summarizing, the Ch. Empl. Comm. says:

"It would be unjust to the larger employers that their factories should be placed under regulation, while the hours of labor in the smaller places in their own branch of business were under no legislative restriction. And to the injustice arising from the unfair conditions of competition, in regard to hours, that would be created if the smaller places of work were exempt, would be added the disadvantage to the larger manufacturers, of finding their supply of juvenile and female labor drawn off to the places of work exempt from legislation. Further, a stimulus would be given to the multiplication of the smaller places of work, which are almost invariably the least favorable to the health, comfort, education, and general improvement of the people." (as cited in Marx, 2006a, p. 556)

The final contrition that tries to disguise the honesty shown at the beginning of the declaration tries to cover the relationship between the expansion of legal restraint and the benefit of the large capital in annihilating the small competition, accelerating, with mediation, the process of centralization. For no other reason, although "Factory Inspectors unceasingly and with justice, commend the results of the Acts of 1844 and 1850" (Marx, 2006a, p. 475), they finally admitted "that the shortening of the hours of labor has already called forth such an intensification of the labor as is injurious to the health of the workman and to his capacity for work" (Marx, 2006a, p. 476). Thus, the political-juridical solution was responsible for taking the labor-power out of the condition of physical destruction imposed by the industry and archaic systems of work at home. However, this solution led the labor-power to the physical destruction by the machinery production, with a differential: when generalizing the second condition, the relative surplus population was restored at acceptable systemic levels, re-establishing more favorable conditions for the capital to purchase labor power.

The whole problem we have discussed above cannot be analyzed apart from a final, fundamental and quite precise determination, namely:

the laborer is nothing else, his whole life through, than labor-power, that therefore all his disposable time is by nature and law labor-time, to be devoted to the self-expansion of capital. Time for education, for intellectual development, for the fulfilling of social functions and for social intercourse, for the free-play of his bodily and mental activity, even the rest time of Sunday (and that in a country of Sabbatarians!). . .. But in its blind unrestrainable passion, its werewolf hunger for surplus labor, capital oversteps not only the moral, but even the merely physical maximum bounds of the working day. . . .

capitalistic production, which is essentially the production of surplus-value, ... produces the premature exhaustion and death of this labor-power itself. It extends the laborer's time of production during a given period by shortening his actual life-time. (Marx, 2006a, pp. 306-307)

Therefore,

By converting part of his capital into labor-power, the capitalist valorizes the value of his entire capital. He kills two birds with one stone. He profits not only by what he receives from the worker, but also by what he gives him. The capital given in return for labor-power is converted into means of subsistence which have to be consumed to reproduce the muscles, nerves, bones, and brains of existing works, and to bring new workers into existence. Within the limits of what is absolutely necessary, the individual consumption of the working class is the reconversion of the means of subsistence given by capital in return for labor-power into fresh labor-power which capital is able again to exploit. It is the production 
and reproduction of the capitalist's most indispensable means of production: the worker. The individual consumption of the worker, whether it occurs inside or outside the workshop, inside or outside the labor process, remains an aspect of the production and reproduction of capital, just as cleaning machinery does, whether it is done during the labor process, or when intervals in the process permit. The fact that the workers performs acts of individual consumption in his own interest, and not to please the capitalist, is something entirely irrelevant to the matter. The consumption of food by a beast of burden does not become any less a necessary aspect of the production process because the beast enjoys what it eats. The maintenance and reproduction of the working class remains a necessary condition for the reproduction of capital. But the capitalist may safely leave this to the worker's drives for self-preservation and propagation. All the capitalist cares for is to reduce the worker's individual consumption to the necessary minimum. (Marx, 2006b, p. 667)

It is possible to see the particular content of the simple circulation $\mathrm{Lp}(\mathrm{C})-\mathrm{M}-\mathrm{C} \ldots$ (Lp) $)^{9}$, and its substantive difference in comparison to any general single circulation $\mathrm{C}-\mathrm{M}-\mathrm{C}$. "The laborer is nothing else, his whole life through" (Marx, 2006a, p. 306), the worker is not a Human being, not substantively free nor equal. The worker is, in and through fetishism (which determine the forms of the capital society), only an ideal spectrum that populates the politics and the law. The employment contract, before regulating relationship between equals, aims to regulate the way of buying and selling the commodity labor-power. The distinction between laborer and labor-power is only formally possible by the constitution of the abstract human being bourgeois (Marx, 2009) -, this fetish that operates in reality is elevated to the mystical (ideal-formal) condition of citoyen (Marx, 2009) in the state sphere, where legal ideology is inspired ${ }^{10}$. The increase in the "laborer's time of production during a given period by shortening his actual life-time" (Marx, 2006a, p. 307) is only possible from the moment the relative surplus population remains in levels at which the available supply of the (commodity) labor-power keeps its price down and its abundant existence.

The drastic reduction of the industrial reserve army, combined with the lowering of average labor productivity, decelerates, on a macroscopic scale, the production of value. The example of the Factory Acts shows that the legal limits imposed on individual capital, in generalizing itself, accelerated the process of destruction of archaic forms of labor, consolidating the era of machinery, or the time until the capital invested "stood on its own feet" (Marx, 2006a, p. 441).

Therefore, state interventions aimed at regulating the forms of exploitation (and management) of the labor-power seek to curb the predatory tendency of capital, by disguising its particular action with the ideology of public interest - using the garments of the "universal subject" (Marx, 2010a, p. 79) -, consistent with the condition of abstract domination of capital. The systemic need of social capital (such as preservation of the labor-power, the formation of relative surplus population) imposes itself on the predatory avidity of the singular capital, in the form of social interest, or universality.

The reason for the modern state is to contribute to the rapid systemic realization of capital by presenting the particular actions necessary for this realization based on universality, the common good, and public interest $\mathrm{t}^{11}$. This makes all state action an administrative action to accelerate the completion of the cycle of realization or even the operation of the countervailing tendencies of capital. As for the social management of the labor-power specifically, the task is to guarantee the labor-power reproduction based on structural necessity. This structural necessity refers to the qualified social availability of labor-power, by avoiding the relative scarcity or recomposing the industrial reserve army, as a way of pressing wages, delaying the trend of decreasing the average profit rate, in addition to politically containing ${ }^{12}$ labor claims that may lead to a social uprising. Social management stops when the relative surplus population of labor-power is consolidated in high levels in society, to the point where the worsening of living conditions leads the workers to challenge the social organization in force. In any case, we are facing administrative actions that, in a political-juridical form, have as their primary determination the accelerated conclusion of the cycle of capital realization. It was in this very spirit that the Brazilian state faced the issues regarding the labor-power in the country, as presented below.

\section{"Papè Satán, papè Satán aleppe!" "13: the "colonial way" ${ }^{14}$ and the labor policy in Brazil}

In the first phase of Brazilian industrialization, the country's social organization was based on a rural accumulation, which had lasted until at least the 1920s. This base offered very weak support for a consistent expansion of industrial capitalism: except for Rio de Janeiro, there was no urban infrastructure compatible with the requirements for the development of industrial capitalism (Rodrigues, 1970). The absence of a comprehensive and systematic legal regulation of labor relations can be explained by the inexistence of a national policy of 
industrial development, as a macroeconomic project, at that time. Brazil's economy was based on the primary sector, led by agriculture for exportation.

This context changes in the 1930s, with a policy of international recruitment of the labor-power (Italians, Spanish and Portuguese), which gradually gives way to native labor, originated from rural areas and the service sectors in urban areas. Also, the coffee crisis released labor-power in the farms, enabling the formation of the first significant relative surplus population (a requirement for industry consolidation). The characteristics of this first national industrialization allowed the employment of a low-skilled labor-power (Rodrigues, 1970).

The particular role played by President Vargas' organization of labor legislation in the first systematic effort to consolidate urban-industrial capitalism in Brazil was well explained by Oliveira (2003, p. 38): Labor laws are part of a set of measures aimed at establishing a new form of accumulation. Thus, the population in general, and specifically the population that came to the cities needed to be transformed into a reserve army. This conversion of a large population into a reserve army for capital reproduction, was apposite and necessary from the mode of accumulation that just started and was intended to be reinforced. There were two main reasons to say that. First, the average horizon for business economic calculation, freed from the nightmare of a perfect competition market, in which it should compete for the use of factors. Second, the labor legislation that equaled reducing - rather than increasing - the price of the labor-power.

it is the abundance of

labor-power in the current

national (and international)

framework, i.e., the existence

of expressive relative surplus

population that allows the

Brazilian state to realign, according to the needs of

capital accumulation in Brazil, its labor policy ...

Moreover, he concludes that it is from there, from the implantation of the labor laws, that a tremendous impulse is transmitted to the accumulation, characterizing a whole new stage for the development of the Brazilian economy (Oliveira, 2003, p. 39). The author's subsequent developments are well-known and point to the corresponding deregulation of labor relations in the rural areas, which has ensured the maintenance of the urban labor-power reproduction costs at low levels ${ }^{15}$. Therefore, it is possible to argue that, in the two simultaneous ways of its global labor policies (regulation and legal deregulation of labor relations) the action of the state at the time of President Vargas was guided to make feasible the systemic reproduction of the forming Brazilian industrial capital.

The establishment of the bourgeois autocracy in 1964, or more precisely, its post-1967 labor policy of political and economic bottleneck, underpinned the realignment of the Brazilian capital - the reorganization of the country's industrial base - with the international imperialist capital. Moved by a logic of subordination to international capital, the model was oriented on two fronts: an intensification in the production of durable goods, with the consolidation of the domestic market supported by a privileged and restricted social stratum that served as the social basis of the regime (concentration of income, therefore, was a structuring part of the model's functioning ${ }^{16}$ ); and a deflationary policy, based on wage and state terrorism, as a way of compressing the costs of reproduction of the mass of workersi ${ }^{17}$.

The growth observed since 1968 was short winded. The international crisis of 1971 and the oil shock in 1974 ended with the hopes of outstanding development. The accumulation boom, leveraged by the consumption of durable goods, quickly depleted the installed capacity that had lain idle since 1962 (Oliveira, 2003). To avoid the stop of the growth tendency, the demand for capital goods had to be remedied through an import policy which, in steady growth ${ }^{18}$, was not accompanied by the internal pace of the development of department I. As a result, the balance of payments became progressively negative in view of the difference in value added between exported manufactured products ${ }^{19}$ and imported capital goods. The deficit in the balance of payments has made the Brazilian state dependent on growing external indebtedness that, once initiated, leads to the vicious circle of debt services, progressively jeopardizing the state budget.

In any case, the comprehensive picture could only be consolidated by favoring the manufacturing industry of durable goods, operating in industrial parks based on components assembly (not on the development of matrices). According to the census at that time, in 1970, Brazil had expanded to 93 million inhabitants, and $55.9 \%$ of the population was living in the $\operatorname{cities}^{20}$ (Paulo Netto, 2014). These figures guaranteed the continuation of a relative population surplus, which, by enabling repressive legislation on labor $^{21}$, allowed to disorganize the workers, leading them to bear, at the extreme limit, the effects of the wage tightening ${ }^{22}$.

Therefore, the same state that, from 1930 to 1945 consolidated the labor laws for urban workers, leaving rural 
labor subject to severe exploitation as a consequence of the alignment with the economic policy of basic national industrialization, imposed - following the historical necessities of accumulation of capital in Brazil, in a new phase of realigning its industrial development with international imperialist capital - the politics of wage tightening and state terrorism, in the period of bourgeois autocracy. For those who claim to be a management issue ${ }^{23}$, they should never lose sight of the fact that this possibility of variation dwells between the limits of the state administrative intervention, in its role of matching labor policies as part of the needs of economic accumulation that, in the Brazilian characteristic of dependent insertion, is guided by the movements of reorganization of the international division of labor. In this spirit, we must analyze the intensification of the discussions on labor legislation from 2015.

Recession and urgency of reforms (which occurred too slowly, in the face of the imminent recession) precipitated President Rousseff's downfall in 2016. Harassed by the international scenario (crisis of 2009 and its late effects in Brazil, from 2015; global economic recession with no apparent signs of recovery; volatility of the financial system and plundering of markets by large speculative capital - and the nation states were not able to systematically combat it; the fourth industrial revolution; debt expansion of virtually all national states), the Brazilian dependent bourgeoisie panicked, once again raising its sociopathic fear (Fernandes, 2008, p. 185) toward the social changes, in the face of a government that was too slow (regarding its administrative capacity) to produce mechanisms to maintain accumulation in Brazil. When aligned with fractions of international capital, the bourgeoisie starts to demand urgent actions to guarantee the production and expatriation of profits and dividends from foreign direct investments (FDIs). This practice was clearly observed in the Petrobras' pricing policy (Brazilian state-owned oil company) as of May 2016. It consists in accelerating plundering of state assets, by expanding its range of participation in the national expropriation of the social surplus-value (which is done by using the federal treasury), and by plundering state-owned companies. The later, in a period of economic retraction, difficulties of capital realization - especially industrial - and doubts about the Brazilian state's ability, in a recessive framework, to control the state deficit, honor commitments and maintain operational even with extremely lean and precarious structures, its administrative capacity to manage the capital accumulation.

The harbingers of a Fourth Industrial Revolution extend the nightmares of the Brazilian bourgeoisie, compared to their real possibilities to incorporate, without state subsidy, production means operating by nanotechnology, biotechnology, cyber-physics systems, new forms of energy storage, synthetic biology and other innovations. By indicating the extinction of approximately 5 million jobs by $2020^{24}$, the technological revolution of this century points to a brutal increase in constant capital, which has been accessible, so far, to large monopolistic conglomerates (often, under conditions of fusion and still with strong contribution of the central national states in the development of science and technology). In this scenario, the continuity of industrial production based on national capital becomes extremely uncertain, extending the submission of the surviving fractions of the industrial bourgeoisie to the international monopoly capital.

The actions aimed at dismantling the protection of labor in Brazil in the post-international crisis of 2009 (whose most intense expressions are the labor legislation changes of 2015 and 2017) are considered double dependent coordination as referred to by Fernandes (2008). On the one hand, these actions must expand the overexploitation of labor, equating, for the imperialist capital, the production of the surplus-value in a context of world retraction in the employment of living labor and drop in profit rates. On the other hand, and as a result of this phenomenon, these actions seek to expand, beyond tolerable limits, the exploitation of labor as a way of remedying the national incapacity to produce technological matrices capable of promoting an autonomous Brazilian industrial development, taking advantage of the surplus labor-power available which is expressed in rising unemployment rates. Therefore, unable to autonomously produce technology, Brazilian capital is submitted to the domain of foreign capital. Its only alternative is to stretch, beyond limits, the overexploitation of labor, equating its rates of profit and its social condition of domination. Thus, it is the abundance of labor-power in the current national (and international) framework, i.e., the existence of expressive relative surplus population that allows the Brazilian state to realign, according to the needs of capital accumulation in Brazil, its labor policy, replacing a social protection essay (as stated at the Constitution of Brazil, 1988) with wild predation.

It is clear that these violent and open assaults that we face keep, as a genetic determination, the particular condition that forms our capital - the colonial way (Chasin, 2000, pp. 35-58). A latifundia rural structure, originated in the colonial period, based on slave labor, and whose production was destined for export; changes occurred by conciliation between the dominant classes (rural and urban), without popular participation and major ruptures; a slow development of the productive forces, and a "hyper late" industrialization, which occurred in sporadic bursts. These elements shaped and determined the form of classes in Brazil, explaining the inherent difficulties of the Brazilian bourgeoisie in carrying out their traditional political tasks, constituting a class that defends national interests. The national bourgeoisie suffered from a structural inability to promote their economic revolutions, depending systematically on state actions (whether economic or extra-economic), including a particularly aggressive interference in the forms of work reproduction. Without ever seeking economic and 
political emancipation, the Brazilian bourgeoisie was formed as class based on agreements, where it permanently reiterate its subordination to the imperialist capital, and by the maintenance of an authoritarian and violent internal domination. It is explained, finally, that the great national economic changes occur systematically by autocratic means, giving to the processes of modernization the appearance of economic miracles, born of authoritarian interference in all sectors of social life.

\section{Final considerations}

The possibility of establishing in Brazil predatory deregulation with brutal exploitation of the labor-power is promoted by a context comprising the Fourth Industrial Revolution, on a global level, that objectively increases relative surplus population, expanding the industrial reserve army. Also forming this scenario is the global stagnation and the difficulty of recomposing the post-1970 profit rates of the imperialist countries. Moreover, the globalization of capital is a characteristic to be observed: it happens both via the FDI (which seeks to extract super profits and obtain easy repatriation); and via the financialization (that withdraws the surplusvalue accumulated in the national states and contributes to consolidate the contemporary priority of accumulation: the viabilization of the capital that generates more capital, $\mathrm{M}-\mathrm{M}^{\prime}$ ). This context, because of Brazilian current relative abundance, makes overexploitation an expedient that is not only possible but indispensable. In other words, the state can again be free from the responsibility of reproducing this particular commodity - the laborer, as the only commodity that is responsible for its own reproduction (Marx, 2006b) - directing the social surplus-value of state funds to encourage capital on other fronts, as a priority, to realize financial capital.

Inflections in (state) macroeconomic policy regarding labor-power management can always be promoted, as observed in examples throughout history (the strikes of 1978/1979, for instance), by an organized uprising of labor. However, the solution of these demands in the political-juridical sphere does not violate the administrative nature of the state of permanently adapting the modalities of social reproduction of the labor-power to the cumulative needs of capital in each historical moment. In Brazil, the changes in labor laws (and in social rights, more broadly) are closely related to the variation in the phases of capital accumulation, which gain phenomenal expression in the economic models adopted throughout our recent history. The struggles of the workers who are moving toward the political-juridical solution can, at most, expand or constrict the range of the state's choices. However, they cannot remove from the state its characteristic as an administrative structure of capital. In this respect, the answers are hopelessly determined by the imperative of realization of capital.

\section{References}

Alighieri, D. (1933). La divina commedia. Bari, Italy: Gius. Laterza \& Figli.

Arbia, A. (2017). A ilusão de controle da incontrolabilidade: Uma análise das formas ideológicas estatais (política e direito) a partir da crítica da economia politica (Doctoral dissertion, Federal University of Rio de Janeiro, Rio de Janeiro, Brazil). Retrieved from https://sucupira.capes.gov.br/ Chasin, J. (2000). A miséria brasileira: 1964-1994 do golpe militar à crise social. São Paulo, Brazil: Ad Hominem.

Colistete, R. P. (2009). Salários, produtividade e lucros na indústria brasileira, 1945-1978. Revista de Economia Política, 29(4), 386-405. Fernandes, F. (2008). Sociedade de classes e subdesenvolvimento (5th ed.). São Paulo, Brazil: Global.

Instituto Brasileiro de Geografia e Estatística. (2004). Tendências demográficas: Uma análise dos resultados da amostra do censo demográfico 2000. Retrieved from https://biblioteca.ibge.gov.br/visualizacao/livros/liv4889.pdf

Lei No. 4.330, de $1^{\circ}$ de Junho de 1964, Diário Oficial da União [D.O.U.] de 3.6.1964. Retrieved from http://www.planalto.gov.br/ ccivil_03/LEIS/1950-1969/L4330.htm

Lei No. 5.107, de 13 de Setembro de 1966, Diário Oficial da União [D.O.U.] de 14.9.1966. Retrieved from http://www.planalto.gov.br/ ccivil_03/LEIS/L5107.htm

Lei No. 13.429, de 31 de Março de 2017, Diário Oficial da União [D.O.U.] de 31.3.2017. Retrieved from http://www.planalto.gov.br/ ccivil_03/_Ato2015-2018/2017/Lei/L13429.htm

Lei No. 13.467, de 13 de Julho de 2017, Diário Oficial da União [D.O.U.] de 14.7.2017. Retrieved from http://www.planalto.gov.br/ ccivil_03/_Ato2015-2018/2017/Lei/L13467.htm

Marx, K. (1986). O capital: Crítica da economia política (2nd ed., Vol. 3, t. 1). São Paulo, Brazil: Nova Cultural.

Marx, K. (2006a). O capital: Crítica da economia política: Livro I: O processo de produção do capital (24th ed., Vol. 1). Rio de Janeiro, Brazil: Civilização Brasileira.

Marx, K. (2006b). O capital: Crítica da economia política: Livro I: O processo de produção do capital (21st ed., Vol. 2). Rio de Janeiro, Brazil: Civilização Brasileira.

Marx, K. (2009). Para a questão judaica. São Paulo, Brazil: Expressão Popular. 
Marx, K. (2010a). Crítica da filosofia do direito de Hegel (2nd Rev. ed.). São Paulo, Brazil: Boitempo.

Marx, K. (2010b). Nova Gazeta Renana. São Paulo, Brazil: Educ.

Marx, K., \& Engels, F. (2010). Lutas de classes na Alemanha. São Paulo, Brazil: Boitempo.

Oliveira, F. de. (2003). Crítica à razão dualista. O ornitorrinco. São Paulo, Brazil: Boitempo.

Paulo Netto, J. (2014). Pequena história da ditadura brasileira: (1964-1985). São Paulo, Brazil: Cortez.

Projeto de Lei No. 4.302-D, de 1998, Diário da Câmara dos Deputados [D.C.] de 23.3.2017. Retrieved from http://imagem.camara.gov.br/ Imagem/d/pdf/DCD0020170323000480000.PDF\#page=54

Projeto de Lei No. 4.330-G, de 2004, Diário da Câmara dos Deputados [D.C.] de 23.4.2015. Retrieved from http://imagem.camara.gov.br/ Imagem/d/pdf/DCD0020150423000620000.PDF\#page=126

Ribeiro, S. (2016, October 31). Cuarta revolución industrial, tecnologías e impactos. Retrieved from https://www.alainet.org/es/articulo/181334 Rodrigues, L. M. (1970). Industrialização e atitudes operárias: Estudo de um grupo de trabalhadores. São Paulo, Brazil: Brasiliense.

\section{Notes}

1 For more on the criticism toward the modern state, see Marx's works during the 1840s - highlighting the articles published in the Rheibische Zeitung (Marx, 2010b), the Kreuznach manuscript (Marx, 2010a), the classics of the Franco-German Annals (Marx, 2009, 2010a, pp. 145-157) and the publication of Vorwärts!, against Arnold Ruge (Marx \& Engels, 2010, pp. 25-52).

2 The first evidence of this dismantling, it is important to remember, is the Bill 4330/2004 (Projeto de Lei No. 4.330-G), voted in haste in the Chamber of Deputies. The bill was then submitted to a slow process in the Senate, where it was appended, in 2016, to Bill 4302/1998 (Projeto de Lei No. 4.302-D), which was even more flexible in its provisions for the employment of outsourced workforce. The bill was passed and became Law 13429/2017 (Lei No. 13.429).

3 The quote continues as follows: when the limits are only known at the very time in which the processes take place, just as events are not rigidly programmable in their dates and time; on the other hand, and contrary to that, it is possible to have a clear idea of the outline, the trends, the necessary basic events. This is widely discernible, identifiable in the long run (Chasin, 2000, p. 79).

4 Insertion added by Marx.

5 The data were collected by the Children's Employment Commission, an inspection and inquiry commission set up by the British Parliament in 1863 to report the working conditions of women and children in English factories. The results of the works were exposed in reports from 1863

6 By increasing individually the numerator of the formula (Marx, 2006a): rate of Surplus-value $=\frac{\text { Surplus-labor }}{\text { Necessary labor' }}$, at the system's expense, i.e., there is a social cost of maintaining the denominator. The choice for the third configuration of the formula presented by Marx (2006b) was made because it expresses the rate of surplus-value-added as "ratio of the times during which those values are produced" (p. 605), i.e., it exposes precisely what we seek to demonstrate: the advantage, for the individual capitalist, in extending the daily working hours (the time spent in surplus labor) in a condition where the working day results in social limitation.

7 All the information and analysis on the development of English Factory Acts was taken from the Volume I of Das Kapital (Marx, 2006a).

8 Insertion added by Marx.

$9 \mathrm{Lp}=$ Labor-power; $\mathrm{C}=$ Commodity; $\mathrm{M}=$ Money; according to Marx's presentation of the forms that make up the cycle of realization in Das Kapital.

10 Marx (1986) stresses this reversed appearance in the following terms: "The capitalist mode of production differs from the mode of production based on slavery, among other things, by the fact that in it the value, and accordingly the price, of labour-power appears as the value, or price, of labor itself, or as wages (Buch 1, Kap. XVII). The variable part of the advanced capital, therefore, appears as capital expended in wages, as a capital-value which pays for the value, and accordingly the price, of all the labor expended in production.... In this formula, the portion of capital invested in labor-power differs from that invested in means of production, such as cotton or coal, only by serving as payment for a materially different element of production, but not by any means because it serves a functionally different purpose in the process of creating commodity-value, and thereby also in the process of the self-expansion of capital [emphasis added]. The price of the means of production reappears in the cost-price of the commodities, just as it figured in the capital advanced, and it does so because these means of production have been purposively consumed. The price, or wages, for the ... working-days consumed in the production of these commodities likewise reappears in the cost-price of the commodities just as it has figured in the capital advanced" (p. 26).

11 This issue was researched in depth by Arbia (2017).

12 Our interpretation, therefore, does not contemplate any difference, in regarding the content, between the terms reform and counter-reform: state administrative actions, in political and legal forms, always aim at the systemic reproduction of capital, enabling or abdicating the physical and social reproduction of the worker. The worker is seen only from the point of view of capital, as a living repository of the substance that creates value, depending on the concrete conditions faced by the capital system at a given historical moment.

13 In Alighieri (1933, p. 30), arriving with Virgil to the fourth circle of hell, Dante is received by Pluto, the demon of wealth, who pronounces the verse. The meaning, as yet undiscovered, has given rise to numerous hypotheses, debates and controversies. When in this fourth circle, Virgil will explain to Dante about the vicissitudes of Fortune; it is there that covetous and the prodigal expiate their sins.

14 Categorization proposed by Chasin (2000, pp. 35-58), as explained later in this article. 
15 First, by preventing the costs of agricultural production to increase when compared to the industrial production, deregulation of labor relations in rural areas play an important role in the cost of urban labor-power reproduction; and secondly, and for the same reason of lowering the real cost of food, it enabled the formation of a rural proletariat serving the commercial cultures of the internal and external markets. Overall, the model allowed the system to ignore the problems of property distribution (which seemed critical at the end of the 1950s), at the same time that the rural proletariat that was formed did not gain the status of proletariat since labor legislation practically does not exist in the rural area and the social security is just a utopia (Oliveira, 2003, p. 45).

16 According to Oliveira (2003, p. 98): a classic type of realization crisis would be in place if the income distribution was egalitarian, and not the opposite, when the national prices remained high.

17 Aiming explicitly at the compression of wages. Such a policy was implemented by a rule in which the calculation of new nominal wages in the private sector was based on the average of real wages in the past 24 months, plus estimates of past productivity and future inflation. This mechanism of correcting nominal wages, in addition to future inflation has been underestimated in official estimates, has contributed to an absolute reduction of wage-consumption in the manufacturing industry (Colistete, 2009, pp. 392-393).

18 From 1966 to 1970, imports of capital goods destined for domestic investment went from US\$ 405.6 million to US\$1,073.9 million. The imports, therefore, grew 1.6 times, much faster than the GNP growth and the growth of the product of the industrial sector as a whole (Oliveira, 2003, p. 103).

19 It should be remembered that, although subsidized, exported manufactured products are rarely able to compete in the international market, given the value gap between labor-intensive goods and goods from countries with a high accumulation rate (high organic composition), produced based on the intensive employment of constant capital.

20 Data from the Instituto Brasileiro de Geografia e Estatistica [Brazilian Institute of Geography and Statistics] (IBGE, 2004) on demographic trends from the 1960s to the 1970s show a population increase of $24.78 \%$ in the South and Southeast Regions, a positive population difference of $13,966,188$.

21 The economic policy of the military period, together with wage tightening, established the prohibition of the right to strike - Law 4330/1964 (Lei No. 4.330) -, the indexation and the end of the employment stability regime - creating the Fundo de Garantia do Tempo de Serviço [Length of Service Guarantee Fund] (FGTS), Law 5107/1966 (Lei No. 5.107). Also, the military government disciplined the union's electoral process, providing that union leaders who advocate ideologies different from the ideals considered adequate for national security were ineligible. These measures were fundamental, for example, to increase the number of overtime hours at work.

22 GDP growth above 10\%, at least from 1968 to 1975 , was not accompanied by a real increase in the minimum wage. Although having gone through one of the most remarkable economic expansions of the second half of the twentieth century, Brazil has become, with other Latin American countries and Sub-Saharan Africa, one of the few areas of the globe where there was not a substantial improvement in income distribution (Colistete, 2009, p. 386). During the period of highest GDP growth, consumer wages even declined or stagnated in real terms in 1970, with modest and wandering growth for the rest of President Médici administration (Colistete, 2009, p. 393).

23 It is necessary to point to the Marx's observation that "all states seek the cause in fortuitous or intentional defects in the administration and hence the cure is sought in administrative measures. Why? Because the administration is the organizing agency of the state" (Marx \& Engels, 2010, p. 39). Also, "the state will never discover the source of social evils in the 'state and the organization of society,.... [Because], from a political point of view, the state and the organization of society are not two different things. The state is the organization of society” (p. 38).

24 For more on the impacts provoked by the Fourth Industrial Revolution, see Ribeiro (2016).

\section{Alexandre Aranha Arbia}

aarbia@gmail.com

Doctor of Social Work from Universidade Federal do Rio de Janeiro (UFRJ)

Assistant Professor at the Department of Social Work of the Universidade Federal de Ouro Preto (UFOP)

\section{UFOP}

Rua do Catete, 166 - Centro

Mariana - Minas Gerais - Brazil

CEP: $35.420-000$

\section{Acknowledgments}

Thanks to the journal's blind reviewers for their contributions.

\section{Funding}

Not applicable.

\section{Authors' contributions}

Not applicable.
Ethics approval and consent to participate

Not applicable.

\section{Consent for publication \\ Not applicable.}

\section{Competing interests}

There are no competing interests. 